\title{
An Investigation into the Impact of Abbreviated Didactic Texting on Language Learning
}

\author{
Seyyed Reza Mousavinia \\ Department of English Language, Andimeshk Branch, Islamic Azad University, Andimeshk, Iran \\ E-mail: Mousavini. seyyedreza@gmail.com \\ AbdolMajid Hayati \\ Shahid Chamran University of Ahvaz, Iran \\ E-mail: majid_hayati@yahoo.com \\ Saeed Khazaie (Corresponding author) \\ Shahid Chamran University of Ahvaz, Iran \\ E-mail: saeed.khazaie@gmail.com
}

Received: 15-11-2013

doi:10.7575/aiac.ijalel.v.3n.2p.220
Accepted: 01-01-2014

Published: 01-03-2014

URL: http://dx.doi.org/10.7575/aiac.ijalel.v.3n.2p.220

\begin{abstract}
This study aimed to investigate whether application of abbreviations in instructional texting (SMS) plays any role in promoting students' performance in learning English through reducing distance and language anxiety. Parallel with examining elliptical features and abbreviations in creating SMS advertisements for addressing their special customers around the world with informal style, to borrow some of the features for the compass of language teaching, 120 participants in two groups at Isfahan university of technology were presented with the same type of content, namely, English grammar notes. They used directions with different lexemes and grammars. To compare the participants' grammar learning, t-test was run. Results indicated that the difference between the performance of learners of the groups was statistically significant. Analyses showed that the didactic SMS with abbreviations and elliptical forms was significantly more effective than the SMS without such features in reducing learners' anxiety, thereby enhancing their language learning. The findings of this study can have implications for both designing texting for advertisements and didactic SMS.
\end{abstract}

Keywords: abbreviation, distance, language anxiety, SMS, style

\section{Introduction}

Discourses are different ways in which humans integrate language with nonlanguage stuff, and the analysis of spoken and written language as it is used to enact social and cultural perspectives and identities is 'discourse analysis' as defined by Gee (1999).

Individuals working in a variety of disciplines are coming to recognize the ways in which changes in language use are related to wider social and cultural development. Discourse is widely used in social theory and analysis, for example in the work of Michel Foucault, to refer to different ways of structuring areas of knowledge and social practice. Discourses in this sense are manifested in particular ways of using language and other symbolic forms such as visual images (Fairclough, 1992).

For at least ten years now, 'discourse' has been a fashionable term. Investigation of discourse requires attention both to language and to action because discourse is language-in-action (Blommaert, 2005). In his study, Bloommaert considers discourse as an entity that includes all forms of meaningful semiotic human activity seen in connection with social, cultural, and historical patterns and developments of use. However, in many cases, underlying the word 'discourse' is the general idea that language is structured according to different patterns that people's utterances follow when they take part in different domains of social life, familiar examples being 'medical discourse' and 'political discourse'. 'Discourse analysis' is the analysis of these patterns. One quickly finds out that discourse analysis is not just one approach, but a series of interdisciplinary approaches that can be used to explore many different social domains in many different types of studies (Jorgensen \& Phillips, 2002).

However, it goes without saying that, these days, advertisement as the issue very much related to discourse has taken different forms. The creative potentiality of advertising as a discourse type which plays with the evocation of imaginative situations has recently drawn the attention of a number of authors (e.g., Carter \& Nash, 1990; Semino, 1997). 
In the study conducted by Mabbettová (2010), it was shown that advertising offers ample opportunities for words to be used effectively with regard to the success in the market. He analyzed the type of lexis used, specialized terminology and made note of the use of neologisms as well as the typical lexical fields in the discourse.

Parallel with advances in the realm of wireless technology, short message service (SMS) as one of the most popular and the plainest features of cell phone has paved the way for employing SMS as an important and effective tool in advertisements. The proliferation and increased use of it by subscribers around the world underlines its status among the citizens of the world. This is in a way that while each day over 1.3-1.5 million people read newspapers all over the world (hit less than half a billion annually), Informal Telecoms and Media (2011) have predicted that by 2015, 15 trillion SMS texts will be sent annually. In the near future, further application of it to iron out some problems or reinforce position of producers and owners of services in the market seems indispensable. In comparison with the conventional manner of advertising, this new communicative channel with the salient merit of instant accessibility gives owners of products and services another opportunity to find their potential customers and keep them continually in contact with the state-of-the-art without having them leave their geographic areas (Ally, 2010).

In this new mode of advertising, advertisers have struggled by employing the least number of word items to have the huge amount of influence over the individuals' minds and decisions. In other words, with the analysis of different types of SMS messages it could be said that parallel with passing of time, advertisers in designing ad messages have continuously changed their prolix routes to the pithy ones to reinforce the advertising message. Furthermore, ensuring that they are addressing the intended group of addressees (i.e., their potential customers), advertisers try to change their ads to the specified ones (e.g., educational ads, medical ads, and computer ads) and employ distinguished types of abbreviation, namely what is assumed to be known by their interlocutor (Widdowson, 2008) (See Figure 1, Iranian ad in the compass of 'education'). Swales (1990) indicates that the use of abbreviations may be seen as evidence for the existence of a specialized discourse community. Such conspicuous application of abbreviation can be readily led into technical registers, the fact that negligence of which culminated in truncated distribution of data.

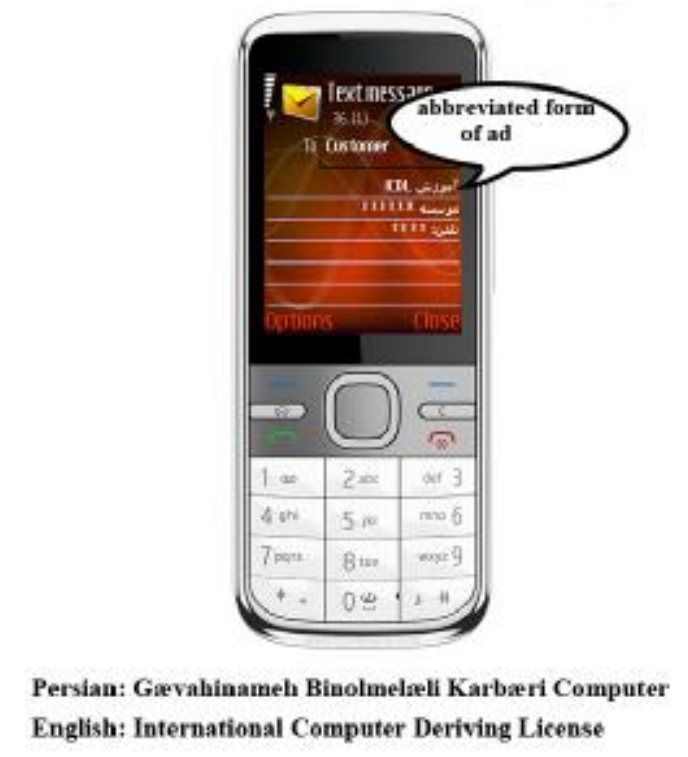

Figure 1. A sample of Iranian SMS ad

As this ad puts students as its potential addressees, the assumption embodied is that all the interlocutors are already familiar with such technical words and expression, at least in the pedagogical settings, and there is no need for further explanation and clarification that is, International computer driving license (ICDL); that is, is the international standard in end-user computer skills. With such presumption, the owner of the service, by reducing the distance, tries to pretend that he/she is in the same profession with the readers of the ad and in this way tries to persuade the students towards buying the service.

This triggers style shift from authoritative style to congenital one. In reality, to reduce their distance with their addresses and in struggling to persuade them towards their products and services, advertisers resort to application of such abbreviations; the usage of technical vocabularies instead of non-technical word items causes informal styles to be imparted from friendly frames to the formal one, that is, it changes the current formal style to informal one. Cadhain (2002) believes that abbreviations and acronyms elicit a sense of group identity as users must be familiar with the lingo of their group to be able to comprehend the SMS language used within the group.

On the other hand, in educational environment like other sectors of society where mobile learning (m-learning) integrates with the information systems of the academic institutions (Colazzo, Molinari, Ronchetti, \& Trifonova, 2005). SMS has changed into a take-for-granted channel of content delivery. Students look for direct access to certain parts of a lecture instead of going through all the material again and again. By recourse to abbreviations as abbreviations was used in SMS advertisement (ad), in structuring content for pedagogical SMS not only are teachers able to solve this 
problem (Zaharieva \& Klas, 2004), they also reduce their distance between themselves and learners and mark parts of the teaching process affect-laden (Blommaert, 2005).

The reduction of distance between teacher and students in a new manner of learning, namely m-learning, stimulates the decreases in language anxiety (Howard \& Major, 2010). Language anxiety or 'the feeling of tension and apprehension specifically associated with second language contexts, including speaking, listening and reading', (MacIntyre \& Gardner, 1994) obstructs L2 learners' growth and reduction of it supports teachers' teaching process and their learners' deep learning (Talebinezhad \& Rezaei Rahimi, 2013).

Likewise, this approach allows adaptation of content at run time to the learners' specific needs. At elementary levels of teaching scenario via SMS, abbreviations and elliptical features could come into view by means of limited sets arranged between teachers and learners. And in more advanced levels they could be developed more and more comprehensively.

As a result, teachers and content developers must design specified types of abbreviation for delivery via SMS. This study compares the intact application of guidelines in teaching English grammar notes with their abbreviated counterparts to see if application of abbreviation in didactic SMS can help in establishing a congenial environment between teacher and students (i.e., reducing distance and language anxiety) and result in their outperformance in learning new contents. More specifically, this study aimed as its objective to find out how much learners can learn from abbreviated SMS and informal style of teachers in addressing their students, and what factors in the interim influence the amount and kind of learning.

\section{Research questions}

Since the pedagogical realm as the domain of specified ads is considered a discourse community with its own members (e.g., teachers, students, content designers), this raises the possibility that didactic SMS has essentially the same potential of using abbreviations as SMS ads. Drawing on application of abbreviations in specified type of ads, this study aimed to employ abbreviations in the field of language teaching through the medium of SMS. Hence, the questions that are concerned in this study are as follows:

1. Do application of abbreviations, elliptical features, and informal style of addressing bear any significant relation to reducing the distance between teacher and students and the level of students' anxiety? And what are their effects on students' performance?

2. Do learners' attitudes towards using abbreviation have any relations with their performance?

\section{Method}

\subsection{Participants}

To carry out the study, as many as 120 out of 128 participants ( 83 male \& 37 female) were selected from among those who took a three-credit course of English (i.e., a perquisite for Iranian students of engineering for achievement of B.S. degree) at Isfahan University of Technology. They were selected from six classes and homogenized through conducting Nelson English language proficiency test (Coe \& Fowler, 1976) '150 A' which seemed suitable for confirming the learners' intermediate level of language proficiency. Their age range was 19-23. The selected participants were then divided randomly into two groups as follows:

Group 1: 60 learners who received the instructional content glossed with non-abbreviated form.

Group 2: 60 learners who received the instructional content glossed with abbreviated form.

While formal non-abbreviated gloss was written for each exercise in group one, for the second group an informal abbreviated gloss was written. In abbreviated SMS, the original letters in words are typically replaced by phonetically similar letters or numbers. For example, the word "to" is commonly replaced by "2" and the word "see" by the letter "c" (http://www.thaindian.com).

\subsection{Instruments}

Questionnaire: As attitude is intricately linked to language learning processes and practices (Kumaravadivelu, 2006), to extract information for the purpose of quantitative part of the research regarding the students' attitudes towards using abbreviated SMS in the process of language learning and its role in reducing language anxiety a close-ended questionnaire was designed. The questions were prepared with and targeted at both groups. Its reliability was calculated through Cronbach's alpha, and it was 0.91. Its validity was confirmed by three experts in the fields of Teaching English as a Foreign Language (TEFL). The questionnaire was delivered to the respondents through e-mail and they were free to complete the questionnaire on their own time-table (See the Appendix).

To gauge the participants' satisfaction of learning language through the medium of abbreviated SMS we administered an interview. By means of the interview, researchers seek the learners' attitude toward using informal style of speech in the process of learning to see if the employment of abbreviation has any effect(s) on reducing the level of language anxiety. On the whole, the interview helps the researchers with the framework of the research. The interview in this study was the guide approach type that is intended to ensure that the same general areas of information are collected from each interviewee (Valenzuela \& Shrivastava, 2008).

English Grammar Placement Test: The test was administered to assess the learners' original knowledge of grammar, that is, to obtain an approximate rating of participants' proficiency of English grammar with a view on excluding the 
grammar points with which learners were already familiar in the learning phase of the study (elementary parts) (www.world-Ennglish.org).

English Grammar Notes: Although all the grammar notes in English book of Grammar in Use, intermediate level, (Murphy, 1989) were taught traditionally in two or three successive semesters), to assess the effect of abbreviated guidelines on learners' performance 30 new grammar notes taught at Iranian Language institutes were selected for conducting the main phase of the study in 15 sessions of an educational year. Finally, those notes were changed into two forms of non-abbreviated (G1) and abbreviated (G2) materials. Examples of non-abbreviated and abbreviated content are displayed in Figure 2.
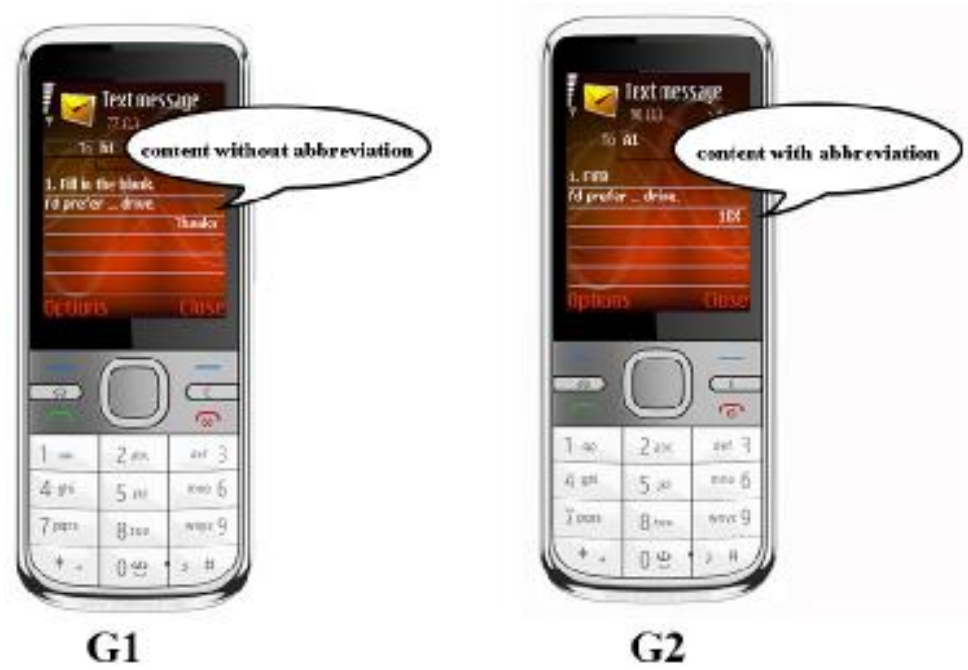

Figure 2. Two types of content (non-abbreviated vs. abbreviated)

In order to collect the required data a 30 items test including three subtypes of test was conducted for testing the students' language proficiency, as shown below:

Subtest I: completing the sentences- In this type of test, a particular word or words in English grammar compass were replaced by blanks and students were asked to write the missing word(s). 10 items of the test were from this type.

Subtest II: multiple-choice questions- Examinees were given grammatically correct and incorrect sentences and asked to choose from four given choices the best answer. 10 items from 30 items of the test were multiple-choice questions.

Subtest III: recognizing and correcting (rectification)- This type of test indicated sentences with errors. The testes were to find the word(s) that needed correction. Then they were asked to write the correct form of it (Jafarpur, 2002). 10 items of the test were recognizing and correcting type.

The value of the test was from 0 to 30 because the subtests were ranked on a 10-point scale and each question in different subtests was ranked on one-point scale. Further, to remove the effect of style (informal vs. formal) spoken modality was employed in designing guidelines on test items.

\subsection{Procedure}

Introduction Phase: To assess learners' proficiency in grammar and to homogenize them into two groups, the same English grammar placement test was administered. The Attitude questionnaire was distributed via mail among learners of both groups for completion. Due to the fact that main goal in this study is to develop new ways of utilizing wireless technology to support effective instruction, immediately after finishing the test, all the details and objectives of the experiment were explained to the participants to meet their needs during the research phase. The introduction session targeted participants of both groups.

Teaching Phase: Within the period of 15 sessions, all the selected grammar notes (see section 3.2. Instruments, new English grammar notes) were taught to students of both groups via the same channel (i.e., SMS), that is, the teacher sent the notes into learners' cell-phones in two manners of non-abbreviated (first group) and abbreviated (second group) contents.

Testing Phase: After the last session ( $15^{\text {th }}$ session), students of both groups took part in the same English grammar test which was composed of three types of test (i.e., completing sentences or fill in the blank test, multiple-choice test, \& recognizing-correcting (rectification) test). It must be borne in mind that each sub-test comprised 10 items.

Interview Phase: Immediately following the tests, 15 students out of 55 from the second group were randomly selected for interview. They were asked to judge whether using abbreviation in the process of teaching could help them in dealing with language learning difficulties. Mention should be made that in the interview special attention was paid to those aspects of content which seemed to have the greatest effects on conducting future studies to investigate what options students prefer. 


\section{Results}

In order to answer the questions the collected data were analyzed using SPSS version 17.

As shown in Table 1, learners were provided with opportunities to learn when abbreviations were introduced to the SMS. The second group of students, who were supplied with abbreviated contents through cell-phones, had better average than the first group in almost all the sub-tests of English grammar test (Total Mean= 7.3). In other words, the suggestion to make is that abbreviations usage creates the possibility of reducing distance and anxiety and enhancing of learning contents.

Table 1. Descriptive statistics: Comparison of learners' performance in non-abbreviated vs. abbreviated groups

\begin{tabular}{cccc}
\hline Group & Subtest type & Mean & $\begin{array}{c}\text { Standard } \\
\text { deviation }\end{array}$ \\
\hline \multirow{4}{*}{1} & Recall (I) & 3.17 & 0.18 \\
& Recognition (II) & 6.55 & 0.2 \\
& Rectification (III) & 1.97 & 0.2 \\
& Total & 3.8 & 0.14 \\
& Recall (I) & 7.32 & 0.2 \\
2 & Recognition (II) & 9.05 & 0.14 \\
& Rectification (III) & 5.55 & 0.23 \\
& Total & 7.3 & 0.15 \\
\hline
\end{tabular}

In addition, the descriptive statistics analysis showed that although students of the second group showed better performance on the test of grammar, they outperformed in test of multiple-choice questions. In other words, the students of the second group did better on multiple-choice test than on either of the other two types (i.e., recall \& rectification tests).

The results clearly indicated differences between the learners' performances in abbreviated and non-abbreviated messages, namely the second group of learners, who were delivered the materials with abbreviated guidelines, outperformed in the three subtests (Table 2).

Table 2. Inferential statistics: Comparison of learners' performance in two groups (non-abbreviated vs. abbreviated)

\begin{tabular}{ccccc}
\hline Sub-test & $\mathrm{t}$ & $\mathrm{df}$ & $\begin{array}{c}\text { Mean } \\
\text { differences }\end{array}$ & Sig. \\
\hline recall $_{1}-$ recall $_{2}$ & -15.1 & 118 & -4.1 & 0.000 \\
recog $_{1}-$ recog $_{2}$ & -9.9 & 118 & -2.5 & 0.000 \\
rec $_{1}-$ rec $_{2}$ & -11.5 & 118 & -3.5 & 0.000 \\
total $_{1}$-total & -15.9 & 118 & -3.4 & 0.000 \\
\hline
\end{tabular}

Note. recog ${ }_{1}-\operatorname{recog}_{2}$ means score of learners of group one in recognition subtest- score of learners of group two in recognition subtest. Also, rec $\mathrm{r}_{1}-\mathrm{rec}_{2}$ means score of learners of group one in rectification subtest- score of learners of group two in rectification subtest

The statistical analysis was done to see if there is a significant relation between the learners' performance and their attitude. Filling in the attitude questionnaire, more than $96 \%$ of students from both groups believed that abbreviation as one of the distinguished features of m-learning could help to facilitate language learning process, namely, their positive attitudes toward employing abbreviations in the realm of language pedagogy highlighted its importance (Table 3).

Table 3. Inferential statistics: Attitudes of two groups of learners

\begin{tabular}{llll}
\hline & \multicolumn{3}{c}{ t-test for Equality of means } \\
\hline Attitude & t-value & df & Sig. \\
Abbreviated & 1.00 & 118 & 0.11 \\
instruction & & & \\
\hline $\mathrm{p}<\mathbf{0 . 0 5}$ & & &
\end{tabular}

The results of the interview confirmed application of abbreviated SMS as a useful device for construction of congenital language learning setting. Generally, the students reported that when their distance with the teachers in an informal setting was reduced they were able to communicate more easily with their teacher and classmates to cope with problems and difficulties. 


\section{Discussion and Conclusions}

Companies focusing on the teen market have the tendency to make use of SMS language in their advertising to capture the attention of their target audience. In fact, advertisers comment that they desire to bring across the impression that they identify with youth culture and discourse (Vranica, 2008). The results reached in this study show similar tendencies about its effect in the realm of pedagogy, that is, abbreviated and non-abbreviated didactic SMS seemed to be independently beneficial to English L2 learners in the process of learning English grammar, with an advantage to the side of the first type. In other words, the virtual world of m-learning not only offers a more convenient environment for students to learn new materials than the real classroom setting, but also application of abbreviations in content delivery through this channel could have remarkable effect on students' performance. By virtue of the fact that teachers, students, and content designers are from the same discourse community, it seems indispensable that researchers in the realm of pedagogy conduct their investigations into other skills and sub-skills of language learning and teaching to see if learning can be further improved when the abbreviation is accompanied by the didactic SMS. It must be borne in mind that although the use of abbreviations in written work and examinations is not that prevalent among students, they have been in use for a long time, and it is not a novel phenomenon only found in SMS language (Crystal, 2008); hence its application in the realm of pedagogy does not need any special type of training.

Of all the success found in the performance of learners of the second group, quite a substantial amount can be attributed to use of abbreviated language. That is, using abbreviations, participants could easily structure their social relationships through reducing their distance with their teacher and counterparts. It is noteworthy that some researchers feel that the invention of cell-phone messaging is considered to be the source for the invention of SMS language. In general, SMS language hence permits the sender to type less and communicate more quickly than one could manage without such shortcuts.

Regarding outperformance of the second group of students in the recall part of the study which involves spelling, the findings of the study reveal that abbreviated SMS is by no means a cause for bad spelling, where in fact, texting may lead to an improvement in the literacy of the user (Plester, Wood, \& Joshi, 2009). In fact, lack of distance among learners paves the way for easy and continuous negotiation of learning content.

Although research supports the use of SMS language, the popular notion that abbreviated text messaging is damaging to the linguistic development of young people persists and many view it as a corruption of the standard form of language. Therefore, it seems necessary for researchers and content designers to employ different strategies to reduce the possible ambiguities which are ensued from the application of abbreviated texts. In this manner, they not only pave the way for other researchers to employ this type language, but also cause the reduction of language anxiety and encourage the learners toward learning language through this channel.

It must be borne in mind that though m-learning makes outdoor learning possible, some citizens show reluctance in using wireless technology in their process of learning due to their own technology illiteracy (e.g., computer \& mobile) and other logistic reasons; therefore the results of the study of this nature where subjects, and conditions are specific need to be cautiously interpreted or generalized.

\section{References}

Ally, M. (2009). Mobile learning: Transforming the delivery of education and training. Athabasca: AU Press.

Blommaert, J. (2005). Discourse: A critical introduction. Cambridge University Press.

Cadhain, S. (2002). Teen textuality and the txt flirt. Retrieved May 18, 2012 from http://www.txt2nite.com/teentextuality-and-the-txt-flirt.html

Carter, R., \& Nash, W. (1990). Seeing through language: A guide to styles of English writing. Oxford: Blackwell.

Coe, N., \& Fowler, W. S. (1976). Nelson English language tests. London: Butler and Tanner Ltd.

Colazzo, L., Molinari, A., Ronchetti, M., \& Trifonova, H. (2005). M-learning and the growth of mobile computing. Journal of E-Learning and Knowledge Society, 3(2), 95-104.

Cook, G. (1992). The discourse of advertising. London: Routledge.

Crystal, D. (2008). The joy of text. Spotlight, 11, 16-21.

Fairclough, N. (1992). Discourse and social change. Cambridge: Polity Press

Gee, J. P. (1999). An introduction to discourse analysis: Theory and method. London: Routledge.

Grammar exercises and tests. Retrieved from http://www.txt2nite.com/forum

Jafarpur, A. (2002). A course in language testing. Tehran: Payame Noor University.

Jorgensen, M., \& Phillips, L. (2002). Discourse analysis as theory and method. London: SAGE.

Klas, W. \& Zaharieva, M. (2004). Mobilearn: An open approach for structuring content for mobile learning environments. Berlin: Springer.

Kumaravadivelu, B. (2006). Understanding language teaching: From method to postmethod. New York: Routledge. 
Mabbettová, M. A. (2010). Printed chocolate advertising: Discourse analysis (master's thesis). Retrieved March 6, 2012 from: http:// www.is.muni.cz/th/209629/pdf

MacIntyre, P. D., \& Gardner, R. C. (1994). The subtle effects of language anxiety on cognitive processing in the second language. Language Learning, 44(2), 283-305.

Major, J. \& Howard, J. (2010). Developing academic language in the classroom: Planning focused interactive opportunities. Dunedin, New Zealand: $12^{\text {th }}$ National Conference for Community Languages and English for Speakers of Other Languages (CLESOL 2010), 1-4 Oct 2010. (Conference Contribution - Oral presentation)

Murphy, R. (1989). Grammar in use (intermediate level). Cambridge University Press.

Plester, B., Wood, C., \& Joshi, P. (2009). Exploring the relationship between children's knowledge of text message abbreviations and school literacy outcomes. British Journal of Developmental Psychology 27(1), 145-161, 23.

Rezaei, S., Mozaffari, F., \& Hatef, A. (2011). Corrective feedback in SLA: Classroom practice and future directions. International Journal of English Linguistics, 1(1), 21-29.

Talebinezhad, M. R., \& Rezaei Rahimi, R. (2013). The Relationship between foreign language classroom anxiety, reading anxiety and reading achievement among Iranian high school EFL students. Iranian EFL Journal, 4(9), 125-141.

Semino, E. (1997). Language and world creation in poems and other texts. London: Longman.

SMS language sparks off unusually spelt baby names trend! (2012, March). Thaindian News. Retrieved from http://www.thaindian.com/newsportal/world-news/sms-language-sparks-off-unusually-spelt-baby-names-

trend_10024677.html

Sukrisno, A. (2010). Discourse analysis on advertisement. Language Circle, 4(2), 103-111.

Swales, J. (1990). Genre analysis: English in academic and research settings. Cambridge University Press.

Valenzuela, D., \& Shrivastava, P. (2008). Interview as a method for qualitative research. Retrieved from http://www.public.asu.edu/ kroel/www500/Interview\%20Fri.pdf

Vranica, S. (2008). Marketers Try to be 'kewl' with text-message lingo. Retrieved from http://online.wsj.com/article/SB120719487786785755.html

Widdowson, H. G. (2008). Text, context, pretext: Critical issues in discourse analysis. Blackwell Publishers.

\section{Appendix}

تعداد
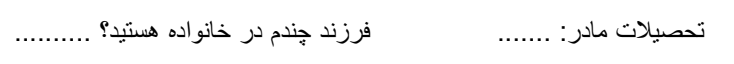

تحصيلات يدر: ............

جنس: ..........

فرزندان خانو اده:

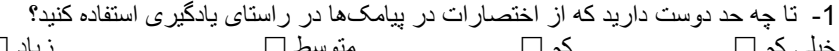

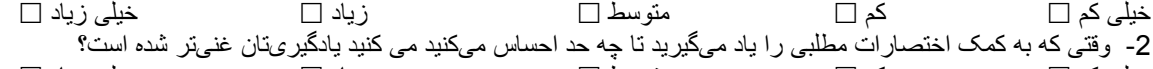

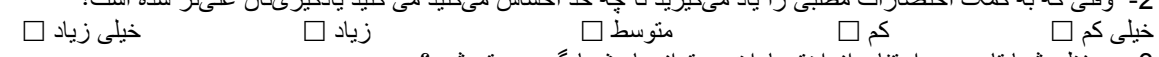
3- به نظر شما تا جه حد استفاده از اختصار ات مىتو اند باعث يادكيرى بهتر شود؟؟ خيلى كم

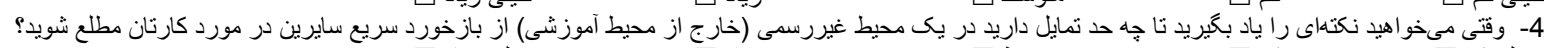

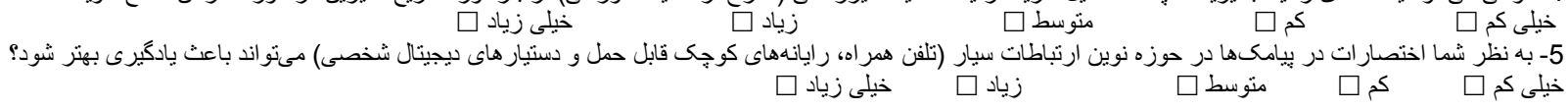

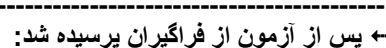

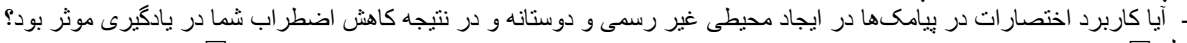
$\square$ خير

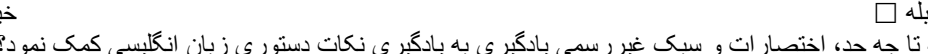

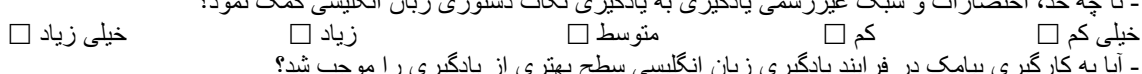
خيلى كم آئ كاريرى 